\title{
Realising political equality: the European Court of Human Rights and positive obligations in a democracy DR RORY O'CONNELL*
}

\author{
School of Law, Queen's University Belfast
}

\section{Introduction}

7 he European Convention on Human Rights (ECHR) speaks of the importance of an 1 "effective political democracy" in its Preamble, though it is only in the first protocol that we find a right to free elections. Article 3 of Protocol 1 (P1-3) reads as follows:

Right to free elections

The High Contracting Parties undertake to hold free elections at reasonable intervals by secret ballot, under conditions which will ensure the free expression of the opinion of the people in the choice of the legislature.

This paper discusses the role of "positive obligations" under P1-3. It identifies positive obligations that might contribute to realising equal political rights in an effective political democracy.

Positive obligations include many different measures that states are obliged to undertake under the ECHR. The diversity of measures contemplated is impressive. The list includes obligations to adopt an effective legal framework to protect rights, duties to investigate allegations that certain rights have been violated, duties to take operational measures in certain cases to protect individuals from violations of their rights, duties to provide information about threats to individuals' rights, duties to provide resources, duties to provide training, and so forth.

In one sense, discussing positive obligations in relation to P1-3 is too straightforward. This Article, unlike other Articles in the Convention, is expressly about positive obligations on the state to do something, in this case to "hold free elections at reasonable intervals by secret ballot" so as to "ensure the free expression of the opinion of the people in the choice of legislature". More importantly, the right to vote and the right to run for election cannot

* Senior Lecturer, School of Law, Queen's University Belfast. I am grateful to participants in the Queen's University Belfast School of Law Workshop on Positive Obligations for comments on an earlier draft of this paper. I am also grateful to students on the QUB taught postgraduate programmes in human rights and governance for discussions on these ideas. Finally, I thank Professor Brice Dickson and Fiona O'Connell for reading earlier versions of this paper. Responsibility for any errors or oversights is mine alone. 
be exercised at all without state measures such as electoral laws, registration processes, voting booths. ${ }^{1}$ At the most basic level, legislature must exist and elections be held for it. ${ }^{2}$

This paper outlines the positive obligations in P1-3 focusing on obligations where the state is required to do more than just change the law. This may mean providing resources or facilities, adopting regulatory frameworks or creating new institutions. The paper highlights specific positive obligations that need to be further developed in the jurisprudence of the European Court of Human Rights (ECtHR). Sometimes these can be developed by analogy with positive obligations recognised in other areas of ECtHR jurisprudence. However, beyond these cases, states should ensure that members of vulnerable and disadvantaged minorities are able to participate in the electoral process and should ensure that dominant political groups cannot abuse their political power to exclude other parties unfairly. This is necessary to realise equal political rights.

The second section of this paper sketches some preliminary points about the Strasbourg institutions' approach to P1-3. After that, the third section identifies circumstances where the ECtHR should apply a more intense scrutiny in P1-3 cases. The fourth, fifth and sixth sections look at positive obligations relating to the right to vote, the right to run for election and the regulation of political parties.

\section{The journey from obscurity}

For a long time P1-3 seemed to lie within a "jurisprudential black hole"3 in the Convention, with applications regularly being dismissed as inadmissible. The early jurisprudence of the Commission treated P1-3 as only being about the obligation to hold elections and not about conferring subjective rights. ${ }^{4}$ Even when the Commission recognised that P1-3 required universal suffrage (though not specified in the text of P1-3), the Commission still rejected the idea that P1-3 conferred "the right unreservedly to every single individual to take part in elections". 5

However, the Commission came to recognise that there were rights implicit in $\mathrm{P} 1-3^{6}$ and the Court confirmed this in its first decision on P1-3 in Mathieu-Mohin v Belgium. ${ }^{7}$ Referring to indications in other parts of the protocol, as well as the preparatory works, the ECtHR held that P1-3 guaranteed "subjective rights of participation - 'the right to vote' and 'the right to stand for election to the legislature". 8 In later cases, the Court refers to these as the active

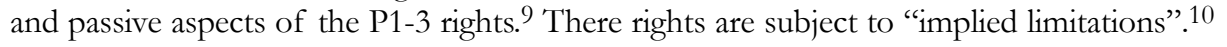

States have a wide margin of appreciation in limiting these rights, subject to review by the ECtHR. The ECtHR:

1 Lécuyer says that political rights are "consubstantial" with positive obligations: Y Lécuyer, Les droits politiques dans la jurisprudence de la Cour européenne des droits de l'homme (Dalloz: Paris 2009), p. 413.

2 Denmark, and Others v Greece (1969) 12 Ybk 1 (The Greek case).

3 Lécuyer, Les droits politiques, n. 1 above, p. 99.

4 D J Harris, E Bates, M O’Boyle, C Warbrick and C Buckley, Law of the European Convention on Human Rights (OUP: Oxford 2009), p. 712, n. 10.

$5 \quad X \mathrm{v}$ Federal Republic of Germany (1967) 10 Ybk 336.

$6 \quad W, X, Y$ and $Z$ v Belgium (1975) 2 DR 114, 30 May 1975.

7 Mathieu-Mohin and Clerfayt v Belgium (1987) 10 EHRR 1.

8 S. 51. Although the right is limited to legislative elections and, indeed, only the popularly elected chamber in a two-chamber system (para. 53). The concurring opinion of Judge Pinheiro Farinha added some important qualifications as to the issue of elections for a two-chamber legislature: the majority of the members of the legislature should be elected and the unelected chamber should not have greater powers than the elected chamber.

9 Zdanoka v Latvia (2006) 45 EHRR 17, paras 105-6.

10 Mathieu-Mohin and Clerfayt v Belgium (1987) 10 EHRR 1, s. 52. 
has to satisfy itself that the conditions do not curtail the rights in question to such an extent as to impair their very essence and deprive them of their effectiveness; that they are imposed in pursuit of a legitimate aim; and that the means employed are not disproportionate ... In particular, such conditions must not thwart "the free expression of the opinion of the people in the choice of the legislature".11

The ECtHR was also careful to stress the wide margin of appreciation available to states in designing an electoral system, especially given the often competing, almost incompatible aims of electoral systems, which have to both "reflect fairly faithfully the opinions of the people" and "promote the emergence of a sufficiently clear and coherent political will". 12 In particular, while any elections must be free, at reasonable intervals, secret and assure the "free expression of the opinion of the people", the protocol said nothing about whether majoritarian or proportional systems should be used. 13 The reference to "free expression of the opinion of the people" referred primarily to freedom of expression and equality. ${ }^{14}$ The Court concluded its general statement of principles by stressing that these principles must be understood in a context sensitive manner and:

assessed in the light of the political evolution of the country concerned; features that would be unacceptable in the context of one system may accordingly be justified in the context of another. ${ }^{15}$

While Mathieu-Mohin established that P1-3 recognised individual rights to run for election and to vote, P1-3 case law continued to be somnolent for much of the 1980s and 1990s. No doubt this was partly due to the wide margin of appreciation reflecting the Court's evident awareness of the political sensitivities of interfering in matters concerning the election of a legislature - matters which go to the heart of the question "Who governs?" Only in the last decade has the jurisprudence become "much richer" with judgments and indeed several important Grand Chamber judgments. ${ }^{16}$ Harris et al. note that there have been important Grand Chamber judgments on the right of prisoners in the UK to vote ${ }^{17}$ and on the possibility for a newly democratic state to ban persons associated with the previous undemocratic regime from running for election. ${ }^{18}$ To this may also be added recent cases, such as the decision on the consociational arrangements in BosniaHerzegovina. ${ }^{19}$

With this rise in case law, involving sometimes very significant issues, it will be important to consider the question of how intensely the Court should scrutinise national situations. In other words, how narrow or wide a margin of appreciation should the Court recognise? This may be especially important if the Court has to deal with claims involving more than merely changing the law and involving positive obligations to resources or new institutions or procedures.

11 Mathieu-Mohin and Clerfayt v Belgium (1987) 10 EHRR 1. For later citation, see Gitonas v Greece App. Nos 68/1996/687/877-9, 1 July 1997, s. 39.

12 Matbieu-Mobin and Clerfayt v Belgium (1987) 10 EHRR 1, s. 54.

13 Ibid.

14 Ibid. In particular, the Court did not believe "that all votes must necessarily have equal weight as regards the outcome of the election or that all candidates must have equal chances of victory". Thus, no electoral system can eliminate "wasted votes".

15 Ibid.

16 Harris et al., Law of the European Convention, n. 4 above, p. 711.

17 Hirst $\mathrm{v}$ United Kingdom (No 2) (2005) 42 EHRR 41.

18 Zdanoka v Latvia (2006) 45 EHRR 17.

19 Sejdic v Bosnia and Herzegovina (2009) 22 BHRC 201. 


\section{Arguments for narrowing the margin of appreciation}

While these recent cases demonstrate a greater willingness to find violations in P1-3 cases, there are still references to a wide margin of appreciation in the case law. Harris et al. suggest that one should not be too critical of the ECtHR case law in this area, pointing to a speech by the Court's President ${ }^{20}$ emphasising that the ECtHR should not be in the business of redesigning the unique democratic structure of each state. ${ }^{21}$ This caution is understandable, however, there are certain circumstances where the ECtHR should be more willing to intervene and if necessary make use of positive obligations. ${ }^{22}$

First, closer scrutiny is justified to protect vulnerable and disadvantaged groups. The representative political process may serve the interests of the majority of the population very well. However, there are dangers that the political process may overlook the interests of minorities or other disadvantaged groups. ${ }^{23}$ The ECHR protects the rights of everyone and the ECtHR should be particularly sensitive to claims that the political process marginalises minorities and other disadvantaged groups. The ECHR Preamble rightly stresses the importance of an "effective political democracy" in maintaining "fundamental freedoms". This can only work if those groups who are likely to see their freedoms threatened are enabled to participate in the political process.

Second, apart from vulnerable and disadvantaged groups, other groups are likely to be disfavoured in the political process: those parties and politicians that are not politically dominant. The ECtHR should be sensitive to the fact that the rules of the political system are drawn up and sometimes enforced by the very parties who secure victory in the political process. This means that politicians and political parties have a vested interest in how they design and enforce the political process. ${ }^{24}$ Where politicians design institutions and enforce rules that maintain their own advantages, then the ECtHR should look closely to see whether incumbent parties are abusing their power and seeking unfair political advantage.

This second type of situation is more difficult than the first. This is because there are legitimate reasons for treating larger parties differently from smaller parties. The ECtHR recognises that an electoral system needs to balance different objectives, including the objective in streamlining representation so that reasonably coherent political viewpoints emerge. ${ }^{25}$ There is a legitimate interest in recognising that one party is more popular than others. For these reasons, the ECtHR has rejected arguments challenging the first-past-thepost electoral system in the UK, ${ }^{26}$ or the 10 per cent threshold to obtain seats in the Turkish parliament. ${ }^{27}$ However, these considerations cannot justify dominant political parties controlling aspects of the political system, such as deciding who can run for election.

20 Judge Costa, "The links between democracy and human rights under the case-law of the European Court of Human Rights”, 5 June 2008, Helsinki.

21 Harris et al., Law of the European Convention, n. 4 above, p. 733.

22 The following arguments derive from John Hart Ely, Democracy and Distrust (Cambridge, Mass: Harvard University Press 1980) and Carlos S Nino, "A philosophical reconstruction of judicial review" (1993) 14 Cardozo Law Review 798.

23 There are numerous criticisms of representative democracy. I am assuming that there is nevertheless merit in representative democracy and trying to improve it, without suggesting that representative democracy is the only or best form of democracy.

24 Samuel Issacharoff, Pamela S Karlan and Richard H Pildes, The Law of Democracy: Legal structure of the political process (New York: Foundation Press Thomson/West 2007), p. 2.

25 Mathieu-Mohin and Clerfayt v Belgium (1987) 10 EHRR 1, s. 56.

26 Liberal Party v UK (1980) 21 D \& R 211.

27 Yumak and Sadak v Turkey (2009) 48 EHRR 4 (GC). 
It is legitimate for the Court to scrutinise decisions closely when they affect a vulnerable and disadvantaged group or unfairly benefit dominant political groups. Recent Strasbourg case law supports these principles. Tänase v Moldova concerned a Moldovan law that prohibited candidates from having dual nationality. The law disproportionately affected members of the opposition parties and impacted disproportionately on Moldovans of Romanian ethnicity. The Grand Chamber found a violation of P1-3, stressing that the Court will be very careful about examining measures that seem to disadvantage opposition parties and minorities. ${ }^{28}$

These points, about vulnerable and disadvantaged groups and the possible abuse by dominant parties, are closely connected to the idea of positive obligations. The danger in each case is that an existing situation disadvantages either minorities or disfavoured political groups. Such situations are unlikely to be rectified only by non-interference; an insistence on non-interference (without positive obligations) might "distort" democracy. ${ }^{29}$ To rectify any of these situations states may need to take active steps.

Having identified the background to the interpretation of P1-3 and suggested that there are circumstances where a narrower margin of appreciation is justified, the next sections explore some of the specific obligations under P1-3 relating to the rights to vote and stand for election, and the regulation of political parties. The sections will identify possible further positive obligations that may be developed, either by reference to well-recognised positive obligations in other areas of the case law, or the principles of protecting minorities and preventing dominant parties abusing their position.

\section{Right to vote}

This section starts by outlining the right to vote case law and highlights several positive obligations that the Court could impose by analogy with existing positive obligations. The section then discusses how the Court could make the right to vote more effective for members of vulnerable and disadvantaged groups.

\section{THE RIGHT TO VOTE CASE LAW}

A freely elected legislature representing the free expression of the opinion of the people requires recognition of the right to vote. There is an implied right to vote in P1-3. For this to be effective there must be an electoral law in place that provides an effective legal framework for the exercise of this right. Such an electoral law would need to specify who is entitled to vote, any requirements as to registration, any procedural requirements as to how the vote should be exercised, and how the secrecy of the ballot should be protected.

The Court has already dealt with situations where someone has been denied a right to vote due to an express legislative prohibition. Whilst the Commission and Court have been generally accepting of "traditional" prohibitions or regulations based on age, residence, or citizenship, more recently the Court has subjected a blanket ban on prisoners in the UK from voting to a searching proportionality inquiry. ${ }^{30}$ As these cases involve legislative

28 Tänase v Moldova App. No 7/08, 27 April 2010 (GC), paras 167-9, 179. On “vulnerable minorities”, see also Alajos Kiss v Hungary App. No 38832/06, 20 May 2010.

29 Fredman argues that judicial policies of protecting negative but not positive rights end up distorting the democratic process; her argument concerns mainly social and economic rights; Sandra Fredman, Human Rights Transformed: Positive rights and positive duties (Oxford: OUP 2008), p. 96. See also Anne Smith and Rory O'Connell "Transition, equality and non-discrimination" in Antoine Buyse and Michael Hamilton (eds), Transitional Jurisprudence and the ECHR: Justice, politics and rights (Cambridge: CUP 2010 forthcoming).

30 Hirst v United Kingdom (No 2) (2005) 42 EHRR 41. See also Frodlv Austria App. No 20201/04, 8 April 2010. 
exclusions from a general law, it is easy to apply a proportionality test to assess whether the exclusion is justified.

The Court has confirmed the Hirst approach in Alajo Kiss v Hungary, where the Hungarian Constitution disenfranchised adult persons who were under the guardianship of another due to reasons of their mental capacity. ${ }^{31}$ The ECtHR held that where a legislative provision disenfranchises "a particularly vulnerable group in society", then the margin of appreciation must be considered to be narrower and the state must offer very weighty reasons for its decisions. ${ }^{32}$ As in Hirst, the automatic nature of the disenfranchisement violated the Convention.

Both Hirst and Alajo Kiss concerned the state's negative obligations. The situation was more complicated in Azizv $\mathrm{v}$ Cyprus, where legislation permitted the applicant to vote but, in practice, he could not. ${ }^{33}$ As a Turkish Cypriot, he was only entitled to register on a list of Turkish Cypriot voters and to vote for a Turkish Communal chamber, but these had not existed since 1963. Consequently, he could not vote at all. This complete exclusion from the franchise was a violation of P1-3. This meant that a failure to legislate to address the situation led to the violation.

The Strasbourg institutions have, until recently, regularly rejected arguments that states should take legislative and administrative steps to extend the right to vote to citizens living abroad. ${ }^{34}$ According to the Commission, a residence requirement was justified because of the need to ensure voters had a connection with the country, the difficulty in candidates presenting their manifesto abroad, the lack of influence of non-resident citizens and, finally, the close connection between residence and being affected by the laws of a legislature. ${ }^{35}$ The ECtHR has generally confirmed this reasoning, ${ }^{36}$ though a recent judgment suggests circumstances when it will uphold right of citizens resident abroad to vote. In Sitaropoulos $\mathrm{v}$ Greece, the Court affirmed the general principle that P1-3 does not require that citizens abroad be allowed to vote. ${ }^{37}$ However, in that case, the Greek Constitution provided that the legislature could adopt legislation providing for the right of citizens resident abroad to vote. This was due to a provision that was adopted in 1975. The ECtHR identified three relevant considerations. First, the Court explained that such a provision could not be allowed to lapse in to desuetude. ${ }^{38}$ Second, the ECtHR suggested that there was a growing consensus on the need to provide for the right to vote of nationals resident abroad. ${ }^{39}$ Finally, the Court noted that a narrower margin of appreciation applied in the right to vote

31 Alajos Kiss v Hungary App. No 38832/06, 20 May 2010.

32 Ibid. para. 41.

33 Aziz v Cyprus (2005) 41 EHRR 11.

34 The ECtHR does not seem to have addressed the situation of someone resident within a state but who happens to be abroad on polling day. Interestingly, the Hungarian Constitutional Court has ruled that there must be legislation in place to address such a situation. Citizens Abroad Voting case decision 32/2004, www.mkab.hu/admin/data/file/690_32_2004.pdf (accessed 21 March 2010).

35 Luksch v Germany App. No 35385/97, 21 May 1997.

36 Hilbe v Liecbtenstein App. No 31981/96, 7 September 1999. The ECtHR has accepted that allowing nonresident citizens to vote for up to a period of 15 years after leaving the UK was compatible with the Convention: Doyle v UK App. No 30158/06, 6 February 2007. The UN Human Rights Committee has rejected as inadmissible a challenge to a residence requirement, but the committee did not address the substantive question: O Colchuin v Ireland Communication No 1038/2001: Ireland, 17 April 2003. For an extreme case of a residence requirement (10 years) being accepted, see Py v France (2005) 42 EHRR 26.

37 Sitaropoulos and Others v Greece App. No 42202/07, 8 July 2010, para. 41.

38 Ibid.

39 Ibid. paras $44-5$. 
cases than in the right to run for election cases. ${ }^{40}$ Due to the combined force of these reasons, the failure to adopt legislation giving effect to the constitutional provision was a violation of the Convention. ${ }^{41}$

This case is not yet final. It is troubling since the Greek Constitution did not explicitly require that nationals resident abroad be allowed to vote. Considering the inverse case non-nationals resident in a state - the Court has not found any obligation to allow them to vote, but arguably there is a stronger case for insisting that such non-nationals be allowed to vote in the country where they reside. ${ }^{42}$

Sitaropoulos demonstrates that the Court is willing to recognise positive obligations (in this case to adopt a law) in P1-3 cases. There are other positive obligations that the ECtHR could develop relating to the right to vote, often drawing on some of the obligations well established in other areas of ECtHR jurisprudence. These are the obligations to protect, to provide information and to investigate.

The positive obligation or duty to protect is relevant. Voters might be subject to threats, intimidation, bribery and other forms of undue pressure. The electoral law should provide sanctions to deter these sorts of activity, and there may be an Osman-type duty to take operational measures to protect persons from interference with their voting rights. ${ }^{43}$

One could envisage positive obligations to provide information in relation to elections. ${ }^{44}$ One might imagine at least three ways in which such a duty would operate. First, there might be a duty to provide information about the electoral system generally. Second, there might be a duty to provide information about the formalities and practicalities required to vote in any particular election. Third, there might be a duty to provide information about the different candidates, parties and positions involved in any election. Fourth, the state needs to publish full results of the election.

Finally, there are circumstances when a positive obligation to investigate may come into play. The duty to investigate cases has mainly concerned alleged violations of the nonderogable rights in Articles 2, 3 and 4. However, duties to investigate have started to appear in relation to other rights, for example, duties to investigate allegations of racial bias in jury deliberations $^{45}$ and duties to investigate allegations of discriminatory motivations in criminal cases (this is usually in connection with Article 2 or Article 3). ${ }^{46}$ This leaves open the argument that there may be a duty to investigate allegations of systematic denial of the right to vote. ${ }^{47}$

These duties to protect, provide information and to investigate may be especially pertinent when the issue is the exclusion of members of a disadvantaged minority from the

40 Sitaropoulos and Others v Greece App. No 42202/07, 8 July 2010, para. 46.

41 Ibid. para. 47.

42 Ruth Rubio-Marin and Rory O'Connell, "The European Convention and the relative rights of resident aliens" (1999) 5 European Law Journal 4. More generally on the rights of non-nationals, see Ruth Rubio-Marin, Immigration as a Democratic Challenge (Cambridge: CUP 2000).

43 Osman v United Kingdom (1999) 29 EHRR 245. For instance, the state has a duty to protect demonstrators and maintain order: Christian Democratic People's Party v Moldova (No 2) App. No 25196/04, 2 February 2010. See also Ollinger v Austria (2008) 46 EHRR 38.

44 The ECtHR found inadmissible (due to non-exhaustion of domestic remedies) a complaint from an NGO that it was not given access to information held by an electoral commission: Geraguyn Khorburd Patgamavorakan Akumb v Armenia App. No 11721/04, 11 May 2009.

45 Sander $\mathrm{V}$ UK (2001) 31 EHRR 1003.

4697 members of the Gldani Congregation of Jehovah's Witnesses v Georgia (2007) 46 EHRR 30.

47 Indeed, the Court has said that the failure to make use of investigatory powers available to an electoral commission may be arbitrary: Georgian Labour Party v Georgia (2009) 48 EHRR 14, para. 130. 
electoral process. The next sub-section looks at the right to vote for vulnerable and disadvantaged minorities.

\section{POSITIVE OBLIGATIONS AND THE RIGHT TO VOTE FOR VULNERABLE AND DISADVANTAGED MINORITIES}

As noted above, the Court has already condemned national rules that exclude vulnerable minorities from the right to vote. This is welcome, but to realise the right to vote there may be a need to recognise positive obligations. Most notably, there are cases where individuals may not be able to comply with the procedural requirements involved in exercising the right to vote. These may include people with disabilities who cannot access a polling booth; people with literacy problems who may not be able to read a ballot paper; prisoners and other persons in places of detention; or people who live in remote localities and who may not be able to access a polling booth. So far, the Court has not considered many of these types of cases. And the one case raising such facts was dealt with unsatisfactorily.

This case was Molka v Poland. ${ }^{48}$ The applicant, a wheelchair user, had been driven to a polling station where he planned to vote in local and provincial elections. The station was not wheelchair accessible and the applicant could only have voted if a stretcher could have been provided to carry him in (which he would have refused to allow). The Court concluded that P1-3 was not applicable as the bodies being elected did not have legislative power. The ECtHR went on to consider whether the public authority's failure to facilitate access violated Article 8 rights. The Court concluded that such an argument was plausible, but had to be assessed in the context of the wide margin of appreciation involved when resources are being distributed. The Court thought the national authorities were better placed to decide how to devote the relevant resources. The Court was influenced by the facts that this was an isolated case, that the applicant could have been assisted by other persons into the building and that Poland had adopted legislative measures providing for access, including specifically for access to venues for national elections - this demonstrated the state was "not oblivious to the plight of disabled voters".

That the state is "not oblivious to" these difficulties does not set a very high standard. While the ECtHR may have been concerned about the possibility of applicants using Article 8 as a springboard for claims to many resources, this concern does not apply in relation to the exercise of the right to vote. Given the importance of the right to vote, the state should enable everyone who is entitled to vote to do so. This requires an effective legal framework but also requires the deployment of resources.

Saying that everyone should be facilitated in voting is perhaps a very sweeping requirement. There may be difficulties in facilitating everyone who is temporarily away from home, or abroad, or disinclined to vote, or who gets lost on the way to vote! Furthermore, there are genuine competing interests against facilitating everyone - there is an argument that an election is a public event and that people should vote (if possible) on the same day and in the same venue to emphasise the public nature of what is being done. In such cases, the ECtHR needs to continue to bear in mind these competing interests that may justify a wide margin of appreciation.

However, there is one situation where the ECtHR should narrow the margin of appreciation and investigate even more anxiously. These are cases where the applicant belongs to a group that may be systematically excluded from political participation, or at least a group that is under-represented in the political process and faces specific challenges 
to participating in that process. Arguably, what human rights law does best is ensuring that such marginalised groups are enabled to enjoy fully their rights on an equal footing with all.

Thanks to its Article 14 (non-discrimination) jurisprudence, the ECtHR already has the conceptual tools to develop positive obligations for these groups. There are four (somewhat related) conceptual tools in the Article 14 jurisprudence that can be used to further participation for disadvantaged groups. First, the ECtHR applies a sliding scale approach to the justification test in Article 14, recognising that certain types of distinction call for more rigorous scrutiny than others. Second, the ECtHR has indicated that the Convention requires special protection be offered to members of a "disadvantaged and vulnerable minority". ${ }^{49}$ Third, the ECtHR has now developed an indirect discrimination test. Where a general rule disproportionately disadvantages a group, then the state must show that it is justified. ${ }^{50}$ Further, the ECtHR is willing to recognise specific positive obligations to achieve equality. ${ }^{51} \mathrm{~A}$ way forward would be for litigants to rely on P1-3 in combination with Article 14's prohibition of discrimination.

Applying these discrimination principles in right to vote cases would proceed as follows. If it can be shown that general rules and procedures about voting have a disproportionate impact on members of certain groups, then the burden switches to the state to justify the rules or procedures. Where the disadvantaged group is one that suffers from systematic discrimination and disadvantage, then the burden of justification should be a very onerous one. Such groups would include racial and ethnic minorities, but also other disadvantaged groups that may be disproportionately affected by voting rules and procedures, such as people with physical or mental disabilities, people with literacy problems, persons in hospitals or places of detention, carers, and, perhaps, the elderly and the young. Other examples of disadvantaged groups might include prisoners and non-nationals. In such cases, the state should show a strong justification for the rules or procedures. Failing this, the state may need to change the rules or procedures or adopt specific positive obligations to allow the exercise of the right to vote on equal terms. This might entail a mere change in the law, but it could also entail deployment of resources. Positive obligations could include education about the importance of voting, ${ }^{52}$ the use of postal voting, voting by proxy, special polling stations in prisons and other places of detention, and ballot papers with photographs and emblems as well as text. These are some mechanisms that would assist in making political democracy "effective" for members of disadvantaged groups, at least in right to vote cases. Right to run for election cases may be more complicated.

\section{Right to run for election}

As well as the right to vote, P1-3 also protects the right to run for elections, sometimes labelled the "passive" aspect of the P1-3 right. Again, the Court has accepted limitations on this right and has been more accepting of limitations of this aspect of the right than of the right to vote.

One of the problems in P1-3 cases is delineating any sharp line between negative and positive obligations. This is in line with the Strasbourg Court's own view that it is not possible or desirable to insist on too sharp a distinction between these types of

49 DH v Czech Republic (2008) 47 EHRR 3 (GC), para. 182.

50 Ibid. para. 175.

51 Oršuš and Others v Croatia App. No 15766/03, 16 March 2010 (GC).

52 The ECtHR has recognised a positive obligation to educate Roma parents about the importance of education: Oršuš and Others v Croatia App. No 15766/03, 16 March 2010 (GC), para. 177. 
obligations. ${ }^{53}$ Therefore, some of these comments on the right to run for election may be analysed either as a question of whether there has been a lawful, legitimate and proportionate interference with the right to run for election, or as to whether there exists an effective legal framework for the enjoyment of P1-3 rights.

Under P1-3, states must adopt rules on the right to run for election that are stable, clear and reasonably certain. There must be a legal basis for decisions about registering candidates. Vague references to the "spirit of the law" do not suffice. ${ }^{54}$ The law must be reasonably clear: if an electoral authority wishes to disqualify someone for not having registered their details accurately, then the electoral law must make clear what details need to be registered. ${ }^{55}$ Similarly, legislation allowing for votes at a particular station to be discounted in certain specific cases or in "other circumstances" is too wide. ${ }^{56}$ A prohibition on "professional clergymen" running for election is only acceptable if it is established who falls under this description. ${ }^{57}$ The law must be reasonably certain: the Court has found, for instance, that sudden, unexpected changes in the judicial interpretation of the electoral law may violate the Convention. ${ }^{58}$ Finally, the law should be stable. Last-minute changes by the legislature of the electoral law may be suspect. ${ }^{59}$

Apart from these requirements as to the existence and quality of the legal framework, the ECtHR has identified process-related obligations. There is a very important passage on matters of process in one of the key P1-3 decisions. In Podkolrina v Latvia, the ECtHR stressed that the rights in the Convention had to be given a "practical and effective" interpretation, not a "theoretical and illusory one". The right to run for election would be illusory if one could be deprived of it arbitrarily. Therefore, any decision to rule a candidate ineligible must be made by "a body which can provide a minimum of guarantees of its impartiality"; the discretion open to such a body "must be circumscribed, with sufficient precision, by the provisions of domestic law"; finally, the procedure must be "fair and objective" and "prevent any abuse of power". ${ }^{60}$ Podkolzina requires that decisions about allowing someone to run should be made by an impartial body, acting according to legal guidance and accompanied by procedural safeguards.

The Court has developed this process further in Grosaru v Romania. The ECtHR found a procedural violation because the bodies that could hear an electoral dispute were largely composed of politicians belonging to parties other than the applicant's. This was a failure to

53 The ECtHR has said this in property and free expression cases: Broniowskiv Poland (2005) 40 EHRR 21, para. 144; VGT Verein Gegen Tierfabriken Schweiz. v Switzerland App. No 32772/02, 30 June 2009, para. 82.

54 Krasnov and Skuratov v Russia (2007) 47 EHRR 46, para. 60.

55 Ibid. para. 60.

56 Kovach v Ukraine App. No 39424/02, 7 February 2008, paras 58-60.

57 Seyidzade v Azerbaijan App. No 37700/05, 3 December 2009, paras 33-5.

58 Lykourezos v Greece (2008) 46 EHRR 7; Paschalidis Koutmeridis and Zaharakis v Greece App. Nos 27863/05, 28422/05 and 28028/05, 10 April 2008.

59 Tänase and Chirtoaca v Moldova App. No 7/08, 18 November 2008. Electoral legislation had been changed less than a year before the next election; further the legislation went counter to the spirit of liberalising legislation that had allowed people to choose to have dual nationality. In a case from Bulgaria, the electoral law had been changed two months before the election: Petkov and Others v Bulgaria App. Nos 77568/01 178/02 and 505/02, 11 June 2009.

60 Podkolzina v Latvia App. No 46726/99, 9 April 2002, para. 35. The UN Human Rights Committee has also found that Latvia has denied people the right to run for election in procedurally dubious ways: Ignatane $\mathrm{v}$ Latvia Communication No 884/1999, 25 July 2001. More broadly, the Human Rights Committee has concluded that there must be access to an independent and impartial body to challenge decisions of electoral authorities: Sinitsin v Belarus Communication No 1047/2002, 30 November 2006. 
provide for an independent body, especially when there was no recourse to a court. ${ }^{61}$ On the other hand, the Court rejected a challenge in the Georgian Labour Party case, where an electoral commission had a high representation from the President's party; however, there was no specific evidence of wrongdoing. ${ }^{62}$ Nevertheless, Grosaru requires that there be an independent body to hear election disputes. This procedural obligation is important as the ECtHR has decided that election disputes do not attract the protection of Article 6 ECHR. ${ }^{63}$ Even more relevantly, this is the type of situation where a suspicion may arise that successfully elected politicians and parties might be able to take advantage of the electoral process. As argued above, it is in cases like this that the ECtHR should be prepared to intervene.

These obligations to create independent bodies to deal with questions about registration and electoral disputes are important precedents. They reflect a restrained procedural solution to problems before the Court. The ECtHR may sometimes ${ }^{64}$ be reluctant for good reasons to be drawn into disputes about whether a candidate should have been allowed to run or other electoral disputes; chief amongst these is the danger of being drawn in to the "political thicket". However, it is more straightforward for the ECtHR to insist that the state should establish an independent body to make decisions on these matters. This approach might be useful in other electoral matters. For instance, the ECtHR has not to date dealt with questions about the drawing of electoral constituency boundaries. ${ }^{65}$ This is another type of question where judicially manageable standards may be rare, and where there is a danger of getting embroiled in political disputes. It is also a situation where dominant political parties might be tempted to redraw constituency boundaries in a partisan way. A plausible solution, suggested by these cases, would be to insist that an independent body does any drawing of electoral boundaries.

\section{MINORITY GROUPS AND WOMEN}

Cases like Podkolzina and Grosaru indicate that the ECtHR is aware of the dangers of states (political parties) controlling certain aspects of the political process. However, there is also a danger that the political process may serve the interests of the majority of the population very well, but marginalise the interests of minorities.

The approach of the Strasbourg authorities does not indicate a great sensitivity to this problem. Rules that formally exclude minorities will be open to challenge. ${ }^{66}$ However, the Commission and Court have not shown themselves to be suspicious of measures that fall short of a formal exclusion. The Commission considered that as long as minority members were entitled to vote and run for election like everyone else, then minority members could not complain of a violation of P1-3 even though they "have no secured representation for

61 Grosaru v Romania App. No 78039/01, 2 March 2010, paras 54-5.

62 Georgian Labour Party v Georgia (2008) 48 EHRR 14, para. 110. Two judges dissented on this issue, Judge Mularoni highlighting criticisms of the OSCE/ODIHR election monitoring body.

63 Pierre-Bloch v France (1997) 26 EHRR 202; Taipe v France App. No 32258/96, 13 January 1997.

64 Not always - the ECtHR has sometimes found that a refusal to register someone as a candidate was a violation; see e.g. Melnychenko v Ukraine (2006) 42 EHRR 39.

65 By contrast, there is a large body of case law on this in the USA.

66 Sejdic and Finci v Bosnia and Herzegovina App. Nos 27996/06 and 34836/06, 22 December 2009 (GC). 
themselves". ${ }^{67}$ The ECtHR's approach to this question would seem to be permissive of state decisions; it seems neither to require nor prohibit special representation. ${ }^{68}$

The ECtHR has addressed language issues in relation to elections. It has rejected challenges to the system of consociationalism in Belgium, where mechanisms are designed to secure equal participation of linguistic groups in the political system. Its attitude on language questions seems likely to be permissive of state decisions in this area thanks to the margin of appreciation. Thus, while the Court accepts the creation of special systems to recognise linguistic communities, it does not require any special provisions for speakers of minority languages. ${ }^{69}$ This broadly permissive attitude is apparent in Podkolzinia where the Court accepted that it was simply a matter of political choice as to what the working language of a legislature should be. Further, the ECtHR did not investigate the possibilities of accommodating minority language speakers using translators or other mechanisms. These cases do not suggest that the ECtHR will require special representation for minorities.

A special case is the representation of women. There is considerable contemporary debate about ensuring balanced gender representation in the political process. ${ }^{70}$ This being so, it is perhaps surprising that the issues of gender quotas, parity laws and the like have not come up in the contentious decisions of the Court. However, the Court has handed down an advisory opinion that suggests that rather than requiring positive action to secure equal gender representation, the Court may be somewhat wary of the idea. The opinion concerned the process by which the ECtHR judges themselves are selected. ${ }^{71}$ The Parliamentary Assembly of the Council of Europe (PACE) elects ECtHR judges on the basis of lists put forward by each state party to the ECtHR. Each state can put forward a list with three names on it; the list may include persons not of the nominating state's nationality. In 2004 and 2005, PACE decided that it would only consider lists that included at least one woman, in an effort to redress the gender imbalance on the Court. The Committee of Ministers asked the Court for an Advisory Opinion on this. The Court ruled that the policy was incompatible with the Convention. It accepted that PACE could try to address gender imbalance and that much of the policy was acceptable. Where the policy went astray was in being an absolute rule. It did not make any exception for small countries where the number of qualified female legal professionals is extremely small. The Court did not believe such states should be forced to nominate a non-national female candidate. Translating this to the context of elections, one might predict that the Court will permit policies to promote greater gender equality, provided there is some possibility for an exception in special cases. This is speculation of course, and does not give any indication as

67 G and E v Norway (1983) 35 DR 30.

68 In Grosaru v Romania App. No 78039/01, 2 March 2010, para. 48, the Court commented that Romania had provided special representation for minority candidates and that it was the country that had the largest number of minority representatives. The Court, however, does not seem to have commented on whether this was required by, compatible or incompatible with the ECHR.

69 The Commission rejected a complaint by a Frisian party that it had not been allowed to submit registration documents in Frisian: Fryske Nasjonale Patrij v Netherlands (1985) 45 DR 240. Similarly, the Commission rejected as inadmissible a complaint by French-speaking Belgians living in Flanders that they had to vote for persons willing to take an oath in Dutch: Clerfayt v Belgium App. No 27120/95, 8 September 1997.

70 See e.g. B Rodriguez Ruiz and R Rubio-Marin, “The gender of representation” (2008) 6 International Journal of Constitutional Law 287.

71 Advisory Opinion on Certain Legal Questions Concerning the Lists of Candidates Submitted with a View to the Election of Judges to the European Court of Human Rights, 12 February 2008. 
to what the Court might think of policies such as all-women shortlists as permitted in UK law, ${ }^{72}$ or the parity law in France. ${ }^{73}$

From these cases, the ECtHR's attitude to minority representation seems to be broadly permissive. States may adopt special representation measures but there does not seem any obligation to do so. This is a question where more judicial restraint is justified than in right to vote cases. This is because the standards are not so clear in addressing problems of under-representation among representatives. First, there is an argument that it is overly essentialist to suggest that people can only be represented by candidates sharing a characteristic with them. Even those who are sympathetic to ideas of group representation are uneasy about this argument. ${ }^{74}$ However, the ECtHR Grand Chamber in Tänase has already indicated that voters have a "right to be represented by MPs who reflect their concerns and political views", referring to voters with dual nationality. ${ }^{75}$ Second, it is sometimes unclear whether a minority's interests are served by having a representative who shares a characteristic, or a number of representatives who, even if they do not share the characteristic, will be concerned to win votes from the minority. Third, there is a wide variety of mechanisms to facilitate minority representation, often involving questions of institutional design. ${ }^{76}$

Finally, minority representation may be affected by the choice and design of the electoral system: majoritarian systems, or proportional systems with high national thresholds, may allocate a disproportionately small number of seats to minority parties. Traditionally, the ECtHR has accorded a wide margin of appreciation in cases involving the choice of electoral system. ${ }^{77}$ Most recently, the ECtHR upheld the 10 per cent quota for a party to be elected to the Turkish Parliament in Yumak, v Turkey. ${ }^{78}$ This high threshold (5 per cent is more common) meant that 45 per cent of voters were left unrepresented in parliament. While the Grand Chamber did not find a violation of P1-3, there were indications of a less deferential approach to questions of choice and design of electoral system. Four judges dissented, while even the majority acknowledged that the exclusion of 45 per cent of voters was "hardly consistent with the crucial role played in a representative democracy by parliament". 79 The majority still found no violation, partly because of the unusual circumstances in which the election took place, the overall context of elections in Turkey, the fact that parties could find ways to circumvent the threshold rule, and, finally, that the Turkish Constitutional Court exercised some review of the threshold rule. ${ }^{80}$

Apart from cases involving the sensitive question of choice and design of electoral systems, there are situations where positive obligations might be appropriate to facilitate minority representation. This is so particularly in light of the comment in Tänase that voters have a right to be represented by candidates who share their views. In situations like

72 Sex Discrimination (Election Candidates) Act 2002.

73 While France is famous for its parity law, it is noteworthy that the French Constitutional Council originally declared such a Bill to be contrary to the Constitution: Constitutional Council Decision 82-146 on the Law Amending the Electoral Code, 18 November 1982.

74 Melissa Williams, "The uneasy alliance of group representation and deliberative democracy" in William Kymlicka and Wayne Norman (eds), Citizenship in Diverse Societies (Oxford: OUP 2000).

75 Tanase v Moldova App. No 7/08, 27 April 2010 (GC), para. 174.

76 See, for instance, the range of options canvassed in the OSCE's Lund Recommendations (1999), www.osce.org/documents/hcnm/1999/09/2929_en.pdf (accessed 31 May 2010).

77 Liberal Party v United Kingdom (1980) 21 DR 211.

78 Yumak and Sadak v Turkey (2008) 48 EHRR 4 (GC).

79 Ibid. para. 140.

80 Ibid. paras 141-6. 
Podkolina, the ECtHR could consider whether the provision of simultaneous translation in parliament, for instance, would facilitate minority representation. If the problem is that members of an impoverished group are unable to raise a deposit to run, then there could be a positive obligation to make an exception in such cases. If the problem is discrimination by political parties, the ECtHR might conclude that the state should adopt laws to prohibit such discrimination. This last point concerns the regulation of political parties and it is to this issue we now turn.

\section{Regulation of political parties}

The ECtHR has developed a considerable body of case law on the rights of political parties, mostly concerned with reviewing decisions to restrict the activities of a party or even to ban them. However, there is also scope for the ECtHR to impose positive obligations on states in relation to political parties. Indeed, the ECtHR has already recognised positive obligations, for instance, to protect politicians and political parties when they are exercising free assembly rights. ${ }^{81}$ The next sub-sections consider possible positive obligations in relation to money and broadcasts, party proscription and questions of internal party democracy and transparency.

\section{MONEY AND BROADCASTS}

A vexed question in any democracy is how to regulate the role of money in politics, in the context of large expenditures by political parties, especially during election time. Some national constitutional courts have developed extensive jurisprudence in this area, as, for example, in Germany. The German Constitutional Court has held that tax exemptions for party donations are unconstitutional and suggests that state financing of political parties, given their constitutional role, is appropriate. ${ }^{82}$ Since then there has been considerable litigation in Germany on the financing system. ${ }^{83}$ The German system of state funding has been upheld in Strasbourg, ${ }^{84}$ but the ECtHR is unlikely to direct states to establish public financing of political parties.

Nevertheless, while the ECHR may not require party financing, it is still possible for a party to argue that a state has violated its ECHR rights by failing to extend financing to it. The ECtHR has already considered one such case. The French National Basque Party (PNB) was denied state funding because it received funding from a foreign entity (the Spanish Basque National Party). The ECtHR concluded that it was justifiable to ban donations by foreign companies, but it was not so obvious that it was justifiable to ban donations by foreign political parties. Still, it fell within the margin of appreciation. 85 Similarly, the ECtHR has rejected the suggestion that P1-3 in itself requires the allocation of time on radio or television to a political party during an election period, unless there is a manifest arbitrariness or discrimination. ${ }^{86}$ The UK courts have already considered such an argument. Political parties in Westminster receive "policy development grants" (PDGs) but only if the party's MPs take their seats in parliament. This had the effect of denying

81 Christian Democratic People's Party v Moldova (No 2) App. No 25196/04, 2 February 2010, para. 25.

82 Party Tax Deduction case [1958] 8 BVerfGE 51, referred to in Donald Kommers, Constitutional Jurisprudence of the Federal Republic of Germany (Durham and London: Duke University Press 1997), p. 201.

83 Kommers, Constitutional Jurisprudence, n. 82 above, pp. 204-15.

84 X v Federal Republic of Germany (1976) DR 90.

85 Parti Nationaliste Basque v France (2008) 47 EHRR 47, para. 47. Judge Rozakis dissented as he believed the majority should have made allowance for the role of political parties within the EU.

86 Partija "Jaunie Demokrati" and Partija "Musu Zeme" v Latvia App. Nos 10547/07 and 34049/07, 29 November 2007. 
PDGs to Sinn Fein, who argued this violated the ECHR. ${ }^{87}$ The Northern Irish Courts ruled that Sinn Fein was not in an analogous position to other parties (since Sinn Fein MPs did not sit in parliament) and so there was no discrimination. While the applicants ultimately failed in these cases, the courts treated the claims as arguable, allowing for the finding of a violation in a suitable case. Therefore, both the ECtHR and UK cases suggest that discrimination-type arguments are plausible.

Similarly, as regards free electoral broadcasts, while there may not be an argument that the state should provide for free electoral broadcasts or other electioneering opportunities, there is a strong argument that any such benefits should be provided on a nondiscriminatory basis. If the rules on election broadcasts were discriminatory, one might imagine an argument that a party or individual excluded from the benefits of free election broadcasts or funded electioneering material might argue that the benefit be extended. The ECtHR should look at the situation to ensure that any such distinction is justified. It may be possible to justify discrimination in such cases if, for instance, the distinction is based on differing levels of support as expressed in election outcomes. Similarly, it may be possible to justify a distinction if a party supports violence or is fundamentally opposed to human rights. This latter situation is the problem posed in "militant democracy" cases and the next sub-section considers this in more detail.

\section{PROHIBITION OF PARTIES?}

One aspect of positive obligations that may be somewhat troubling is the idea that there may be a positive obligation to prohibit certain types of party. Both Article 11(2) and Article 17 ECHR allow for the possibility that a party or individual may be banned, ${ }^{88}$ either as a proportionate response to a threat to one of the Article 11(2) legitimate interests, or in extreme cases because the party or individual is aiming at the "destruction" of the rights and freedoms in the Convention. Provided certain conditions are met, these provisions permit a state to ban a political party.

Is there then a positive obligation to ban certain parties? Fox and Nolte floated the suggestion that any international law right to democracy might include just such a positive obligation, before concluding that the decision to ban a party was such a fact-sensitive and political decision that it would be impractical to have an international law obligation of this nature. ${ }^{89}$ More recently, Brems has emphasised Article 4 of the Convention on the Elimination of Racial Discrimination (CERD), which requires states to proscribe racist organisations, a requirement which presumably includes political organisations. ${ }^{90}$

Until recently, the position of the ECHR has been the one sketched above - any decision by a state to ban a party must be justified under Article 11(2). ${ }^{91}$ However, in the Batasuna cases, the ECtHR seems to envisage the possibility that there may be a positive obligation to ban certain parties. ${ }^{92}$ The cases concerned the Spanish law allowing for the

87 Sinn Fein's Application for Judicial Review [2003] NIQB 27, 10 April 2003 and in the Court of Appeal [2004] NICA 4, 4 February 2004.

88 The Court has rejected a challenge by a Belgian politician who was banned from running for election for 10 years after he disseminated racist electioneering literature: Feret v Belgium App. No 15615/07, 16 July 2009.

89 Gregory Fox and Georg Nolte, "Intolerant democracies" (1995) 36 Harvard International Law Journal 1, pp. 63-8.

90 E Brems, "Freedom of political association and the question of party closures" in Wojciech Sadurski (ed.), Political Rights Under Stress in 21st Century Europe (Oxford and New York: OUP 2006), p. 131.

91 Lécuyer seems to suggest that Zdanoka, Refah Partisi and other cases may support a positive obligation to defend democracy: Lécuyer, Les droits politiques, n. 1 above, pp. 414, 418-9.

92 Herri Batasuna v Spain App. Nos 25803/04 and 25817/04, 30 June 2009. 
proscription of a political party because of its support of political violence. The ECtHR accepted that there was evidence of support for political violence as to make the proscription a proportionate response. However, it also went on to indicate that such a conclusion was in accordance with the state's positive obligations. ${ }^{93}$ Too much should not be read into this passage. The Court does not quite say that there is a positive obligation to ban a political party. Nevertheless, the language leaves open the possibility to argue that the state may have a duty to ban certain political parties.

Apart from possible cases such as Article 4 CERD where the state has accepted such an obligation, this would seem to be a positive obligation too far. Fox and Nolte were right to stress the fact-sensitive and political nature of such judgments. Other scholars too have stressed the need for political actors to make very careful decisions when deciding how to react to undemocratic political parties. ${ }^{94}$ It is difficult to see how a court - especially a supranational court - would be in a position to make such judgments.

\section{INTERNAL PARTY DEMOCRACY AND TRANSPARENCY}

Apart from these examples of positive obligations, there are arguments supporting positive obligations to promote internal party democracy and to support transparency regarding party finances.

Mersel has argued for a duty to promote internal democracy within political parties. This is necessary to support the "representative and participatory functions" of democracy and to counteract oligarchy, among other reasons. 95 While this is a novel suggestion, some constitutions impose requirements on political parties. ${ }^{96}$ Indeed, one of the most famous constitutional decisions in this area - the German Federal Constitutional Court's decision to ban the Socialist Reich Party - was explicitly based on that party's undemocratic hierarchical ordering. ${ }^{97}$ There are even examples of this in the United States Supreme Court. The Supreme Court was able to apply constitutional standards to the Democratic Party in the South to prohibit all-white party primaries. ${ }^{98}$ Given the importance the ECtHR attaches to the protection of minorities, a positive obligation on the state to prohibit

93 “Selon la Cour, un tel pouvoir d'intervention préventive de l'Etat est également en conformité avec les obligations positives pesant sur les Parties contractantes dans le cadre de l'article 1 de la Convention pour le respect des droits et libertés des personnes relevant de leur juridiction. Ces obligations ne se limitent pas aux éventuelles atteintes pouvant résulter d'actions ou d'omissions imputables à des agents de l'Etat ou survenues dans des établissements publics, mais elles visent aussi des atteintes imputables à des personnes privées dans le cadre de structures qui ne relèvent pas de la gestion de l'Etat. Un Etat contractant à la Convention, en se fondant sur ses obligations positives, peut imposer aux partis politiques, formations destinées à accéder au pouvoir et à diriger une part importante de l'appareil étatique, le devoir de respecter et de sauvegarder les droits et libertés garantis par la Convention ainsi que l'obligation de ne pas proposer un programme politique en contradiction avec les principes fondamentaux de la démocratie . . ."; Herri Batasuna v Spain App. Nos 25803/04 and 25817/04, 30 June 2009, para. 82.

94 G Capoccia, Defending Democracy: Reactions to political extremism in inter-war Europe (Baltimore: Johns Hopkins University 2002).

95 Yigal Mersel, "The dissolution of political parties: the problem of internal democracy" (2006) 4 International Journal of Constitutional Law 84, pp. 96-8.

96 Mersel cites Poland's requirement that parties respect equality and participation, while other states ban secret or paramilitary parties or religiously based parties: Ibid. p. 110.

97 Socialist Reich Party case 2 BVerfGE 1 (1952), referred to in Kommers, Constitutional Jurisprudence, n. 82 above, p. 218.

98 Smith v Alright (1944) 321 U.S. 649; Terry v Adams (1953) 345 US 461. 
discrimination by political parties in terms of their membership and selection of candidacy rules is one possible avenue for litigants to pursue. ${ }^{99}$

Finally, there may be positive obligations to ensure that the financing of political parties is transparent. The promotion of transparency regarding the finances and property of parties and candidates is a legitimate aim on the Convention, so states may require parties and individual candidates to disclose information about these matters. A step further would be to oblige the state to compel disclosure - is there Convention support for this? An admittedly imperfect analogy may be with the environmental rights cases like Lopez Ostra, Guerra and Oneryildiz: ${ }^{100}$ When a private enterprise is engaged in hazardous activity and the state has knowledge of that activity, the state is under a duty to provide information to individuals affected so they may vindicate their rights. To develop the analogy, political parties and individuals are looking for voters to vote for them. So that the voters might exercise their rights intelligently and so that the free (informed) opinion of the people might be ascertained, there may be an obligation to insist on transparency about the financing of political parties and individuals contesting elections. This is, indeed, the conclusion to which the Venice Commission ${ }^{101}$ and the Parliamentary Assembly of the Council of Europe have come. ${ }^{102}$

\section{Conclusion}

This paper has highlighted some of the positive obligations identified by the ECtHR in relation to P1-3. It has also discussed some possible positive obligations which may be developed in the future. Some of these may be developed by analogy to positive obligations already recognised in other parts of the ECtHR jurisprudence (duty to protect, investigate, perhaps provide information). Beyond this, realising the ECHR's vision of an "effective political democracy" requires the Court to be attentive to the needs of minorities and nondominant parties. In these cases, the ECtHR should adopt a more intense scrutiny and consider the use of positive measures.

There is a unifying theme to many of these positive obligations. Whether it comes to ensuring that members of minority groups are registered to vote, ensuring that party finance rules are non-discriminatory, or preventing dominant parties from unfairly abusing a position of power, the underlying value is equality. As long ago as the Mathieu-Mohin case, the ECtHR recognised the importance of political equality. This article has suggested some positive measures that are necessary to realise the promise of equal political rights.

99 See e.g. the recent challenge by the British Equality and Human Rights Commission to the legality of the British National Party: Equality and Human Rights Commission, "Court ruling in legal challenge to BNP's constitution", press release, 28 January 2010.

100 Lopez Ostra v Spain (1994) 20 EHRR 277; Guerra v Italy (1998) 26 EHRR 357; Oneryildiz v Turkey (2005) 41 EHRR 20.

101 European Commission for Democracy through Law (Venice Commission), Guidelines on the Financing of Political Parties (Strasbourg: Council of Europe 2001).

102 Parliamentary Assembly Recommendation 1516 (2001) on the financing of political parties 2001. 
